\title{
Research on Combined Hot Extrusion Forming Process of Alternator Poles
}

\author{
Cheng Yang ${ }^{1,2}$, Shengdun Zhao ${ }^{1}$ \\ ${ }^{1}$ School of Mechanical Engineering, Xi'an Jiaotong University, Xi'an, China \\ ${ }^{2}$ School of Metallurgical Engineering, Xi'an University of Architecture and Technology, Xi'an, China \\ Email: yang.cheng@stu.xjtu.edu.cn,sdzhao@mail.xjtu.edu.cn
}

Received July 2013

\begin{abstract}
Based on the structure analysis of alternator poles, two closed die forging steps in one heat forming process of alternator poles were put forward, as well as the forming die system. Firstly, a thicker bottom base of alternator poles was performed by radial forging, then the middle boss and pole claw were forming on the bottom base by backward extrusion. A 3-D coupled thermo-mechanical finite element model was created. The billet deformation, metal flow and forming load were obtained. The results showed that a filling well forging without overlap defects could be obtained by this process, and that the forming load at the first step increased slowly, but the load increased sharply at the second step when the middle boss was filling completely by the former process. An improved process was put forward, which changed the flow mode in the second forging step; it can considerably reduce the final forging load.
\end{abstract}

Keywords: Radial Forging; Backward Extrusion; Alternator Poles; Closed Die Forging

\section{Introduction}

According to the statistics of china association of automobile manufactures, in china the yield and sales of automobile were 19.27 million and 19.3 million respectively in 2012, both had reached all time high. Alternator poles are used in pairs in modern car generators, along with the rapid growth of the auto industry; they need to be produced in large amounts. Usually they are produced with varying cold, warm or hot forging processes [1-8]. There are from five to nine single forging stages. A typical hot forging process includes two pre-forming operations combined with forming, trimming and sizing. Cold forging is done with forward extrusion, setting, heading, piercing, trimming (on separate machines), bending and sizing operations. Warm forging is based on lateral extrusion, followed by heading, trimming, cupping, bending, piercing and sizing. All the processes in use have some shortcomings, such as high cost and inefficient. Therefore, analyzing the forming law, improving forming method and decreasing forming cost have been problems urgent to be solved.

Precision closed die forging has the advantages such as reasonable tissue flow direction, good surface, no flash, no trimming process and intrinsic performance, which lead to material saving, better mechanical properties and higher productivity etc. Based on the structure analysis of alternator poles, two closed die forging steps in one heat of alternator poles forming process was put forward, as well as the forming die system. A 3-D coupled thermo-mechanical finite element model was created, which was analyzed by the software DEFORM-3D. The billet deformation, metal flow and forming load were obtained. The results showed that a filling well forging without overlap defects could be obtained by this process, and that the forming load could considerably reduced by the improved process.

\section{Process and Die Design of Two Closed Die Forging Steps in One Heat of Alternator Poles}

The structure of alternator pole, as shown in Figure 1(a), is axial symmetry. It can be divided into bottom base, middle boss and pole claw, as shown in Figure 1(b) and Figure 1(c), respectively. The bottom base, which looks like a gear, can be formed by radial forging. The middle boss and pole claw can be formed by forward extrusion or backward extrusion.

Based on the structure analysis, a new forming process was put forward. Firstly, a thicker bottom base, as shown in Figure 2(b), was formed by radial forging on ring billet, as shown in Figure 2(a), and secondly the middle boss and pole claws, as shown in Figure 2(c), were formed by backward extrusion on the thicker bottom base. 
Tool-set of the forming process is shown in Figure 3. The heated ring billet is put on the counterpunch of first step tool-set, as shown in Figure 3(a), to form the preforgings. Then the pre-forgings is taken out from the first step tool-set and immediately put it into the second step tool-set to form the final forgings, as shown in Figure

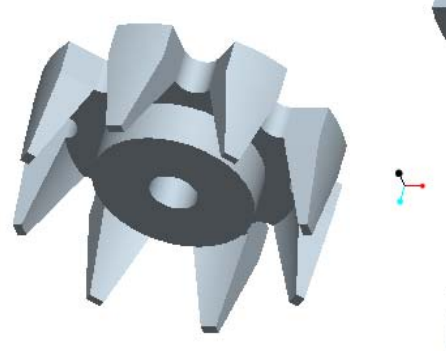

(a)

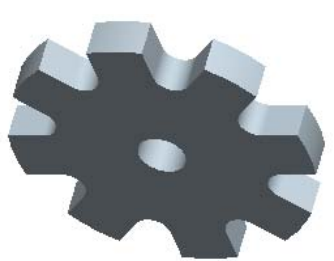

(b)

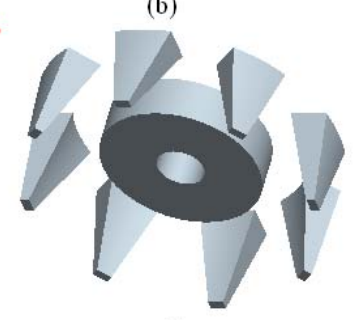

(c)

Figure 1. Structure analysis of alternator poles (a) Structure of alternator poles; (b) Bottom base of alternator poles; (c) Middle boss and pole claw of alternator poles.

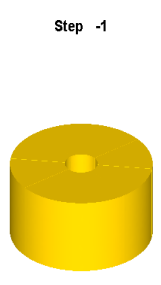

(a)

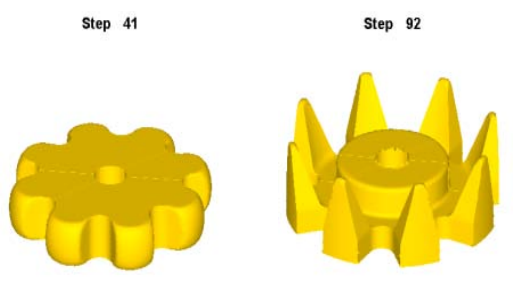

(b)

(c)
Figure 2. Two closed die forging steps in one heat forming process (a) Initial billet; (b) Pre-forging; (c) Final forging.

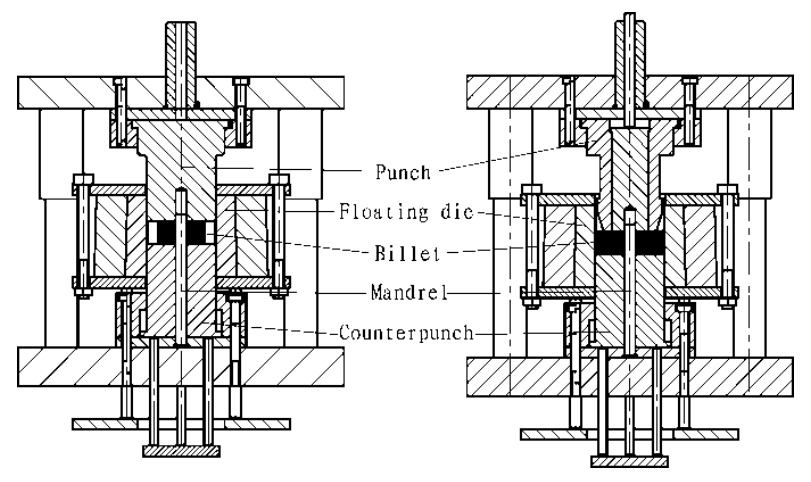

(a)

(b)

Figure 3. Tool system for alternator poles forging (a) First step tool-set; (b) Second step tool-set. 3(b). The main parts of the both steps tool-set are the punch, the counterpunch, the mandrel and the floating die [9]. The punch and the counterpunch form the outer contour of the forgings. The floating die partially forms the outside contour and guarantees an exact movement of upper and lower die. To support the material flow into the claws, the floating die is movable in a vertical direction. Additionally, the mandrel is centering the billet during the deformation, which dives axially into the counterpunch.

\section{Finite Element Analysis}

\subsection{Simulation Models}

For evaluation of the feasibility of the proposed precision forging technology, 3-D finite element simulation has been performed, using a commercially available finite element program, DEFORM-3D. The program works according to the rigid-plastic material behavior model.

The material used for modeling was AISI1010 and the stress-strain relation of the material is got from thermal simulation experiment. The material model is considered as elasto-plastic with Von Misses yield criterion, isotropic hardening. The punch, floating die, mandrel and counterpunch are assumed to be the rigid bodies.

Because of axial symmetry, a portion corresponding to a tooth was used for analysis. Contact of specimen with die surfaces and punches were supposed to obey coulomb law of friction. Approximately, 50000 and 30000 rectangular elements were designed for the forming billet and tools, respectively. Moreover, the calculations were performed by remeshing, so that the divergence of the calculations due to excessive deformation of the elements was prevented.

The simulation processes of the two closed die forging steps in one heat of alternator poles are:

The billet will be heated to $1100^{\circ} \mathrm{C}$ and the tools will be heated to $200^{\circ} \mathrm{C}$.

The heated billet will be moved into the tool-set of first step, which will take 10 seconds. At this stage, the billet exchange heat with the air. Convection coefficient is $0.02 \mathrm{~N} / \mathrm{sec} / \mathrm{mm} / \mathrm{C}$.

The billet will be put on the counterpunch waiting for forming, which will take 5 seconds. Heat transfer coefficient is $11 \mathrm{~N} / \mathrm{sec} / \mathrm{mm} / \mathrm{C}$.

First step forging, the punch velocity is $100 \mathrm{~mm} / \mathrm{sec}$.

The pre-forgings will move from the first step tool-set into the second tool-set, which will take 10 seconds. At this stage, the billet exchange heat with the air.

The pre-forgings will be put on the counterpunch waiting for forming, which will take 5 seconds. Heat transfer coefficient is $11 \mathrm{~N} / \mathrm{sec} / \mathrm{mm} / \mathrm{C}$.

Second step forging, the punch velocity is $100 \mathrm{~mm} / \mathrm{sec}$.

Post-treatment of forgings. 


\subsection{Billet Deformation Analysis}

The billet deformation analysis of first step using finite element analysis is shown in Figure 4. The initial analysis object is one eighth of a ring billet. Then the billet was forging by the punch, in the early stages of forming, the material in the middle section flowed faster than the material in the interface region because of the friction force on the punch and counter punch, no matter either direction, as shown in Figure 4(a). The bulging deformation was observed in compressed billet, forging like a gear was formed. In the final stage, as shown in Figure 4(b), similar phenomena as mentioned above, namely, bottom base of the alternator poles was forming, were observed.

Figure 5 shows the deformation of the billet at the second step. At first, the material at the middle part flowed upward, but the material of the tooth part flowed radial direction, as shown in Figure 5(a). Once the radial direction flow reached the floating die, it changed its direction to flow into the pole claw cavity, as shown in Figure 5(b). The middle boss cavity flow and the pole claw cavity flow were almost at the same speed, and the height of both part were the same, as shown in Figure 5(c). As forging continued, the middle boss cavity was partly full of, little material flowed into the corner, most of material flow changed its direction, as shown in Figure 5(d). When the middle boss cavity is completely full of, the material of the middle boss cavity will be pushed by the punch to flow into the pole claw cavity, as shown in Figure 5(e). In the final stage, as shown in Figure 5(f), similar phenomena as mentioned above, namely, the material of the middle boss cavity flowed into the pole claw cavity, were observed. A filling well tooth was formed.

\subsection{Forging Load Analysis}

Forging loads are carefully examined because excessive load will cause the die to expand, impairing the accuracy of the forged parts and reducing die life. Forging loads using moving floating die and mandrel die designs are shown in Figure 6. At the first step forming, the forging load increased slowly, as shown in Figure 6(a) and Figure 6(b), which increased from 0 to $178 \mathrm{kN}$. When the pre-forging was moved into the second step tool-set, the forging load had a decrease at first because the tool-set was exchanged, as shown in Figure 6(c). Then the forging load increased slowly from $96.5 \mathrm{kN}$ to $213 \mathrm{kN}$ at the early stage of the second step forging, as shown in Figure 6(d). As forging continued, once the middle boss cavity was partly full of, most of material flow in the middle boss cavity changed its direction, resulting in a difference in the forging loads, as shown in Figure 6(e). The load increased sharply to $271 \mathrm{kN}$, an increase of $27.2 \%$ when compared with the punch stroke of $27 \mathrm{~mm}$. An even larger increase of forging load can be seen after the middle boss cavity was completely full of. With the free flow considerably reducing, the load increase more and more quickly, as shown in Figure 6(f). At last, the final forging load of a tooth reached $1450 \mathrm{kN}$.

From the forging load analysis, at the second step forging, when the middle boss cavity was full of metal, material of this cavity will change its flow direction and will be pushed by the punch to flow into the pole claw cavity. As the free flow considerably reducing and the

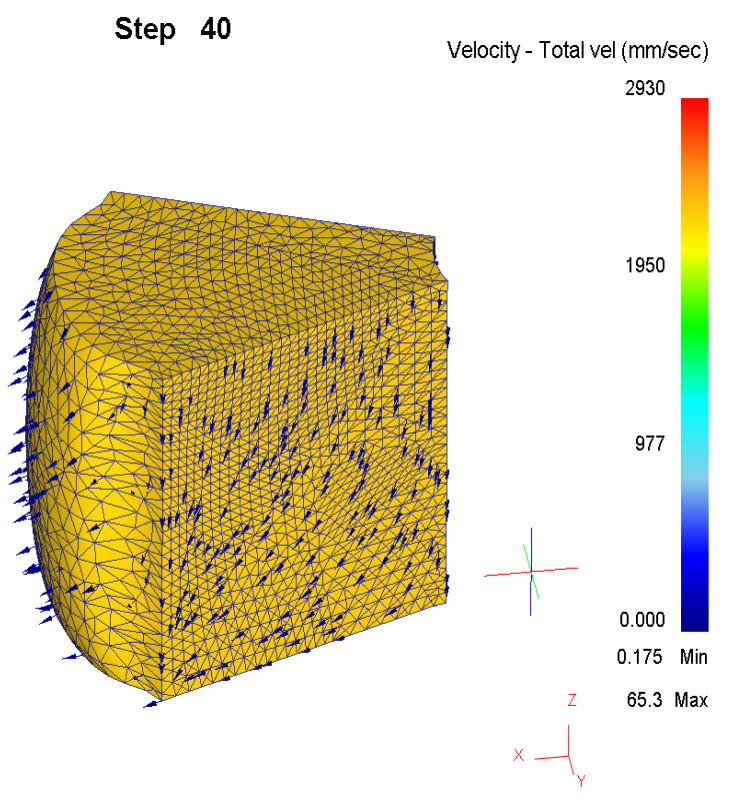

(a)
Step 85

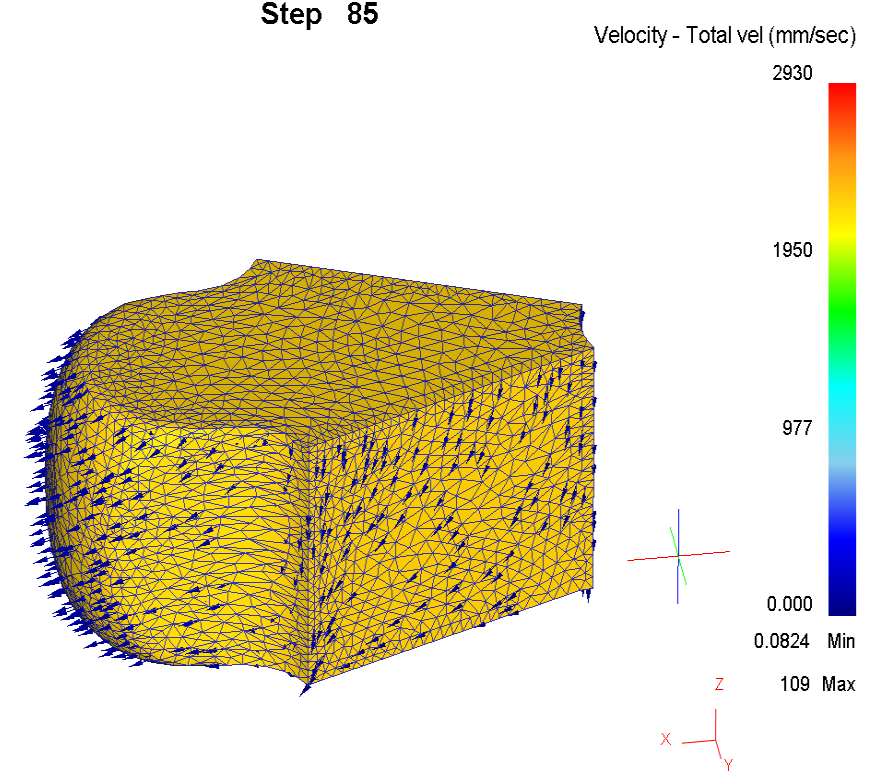

(b)

Figure 4. Billet deformation analysis of first step forging: (a) 40step; (b) 85step. 


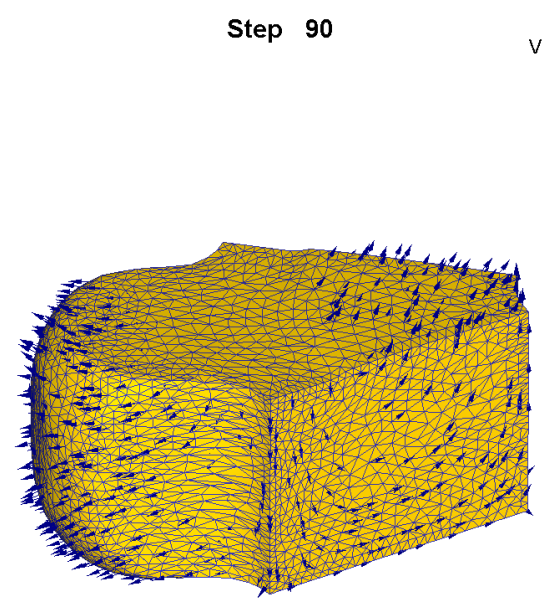

(a)

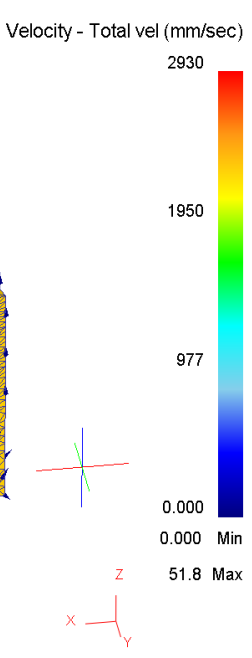

Step 135

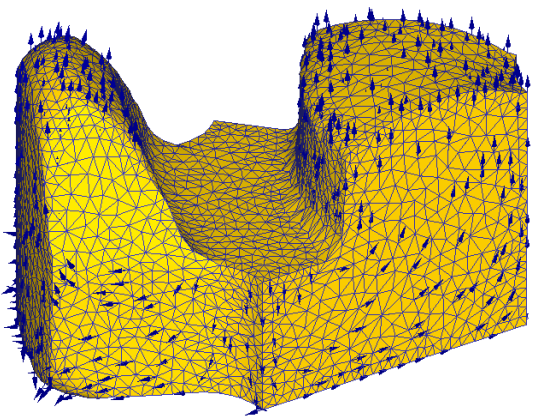

(c)

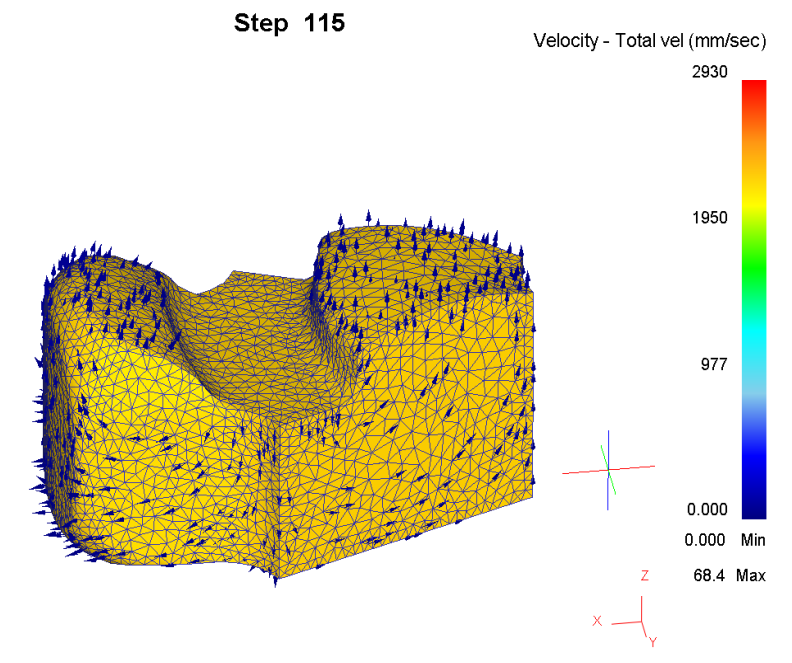

(b)

Step 140 Velocity - Total vel $(\mathrm{mm} / \mathrm{sec})$ 2930

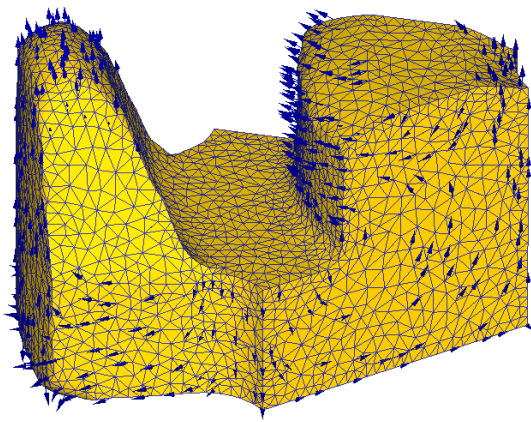

1950

(d)

Step 149

Velocity - Total vel $(\mathrm{mm} / \mathrm{sec})$

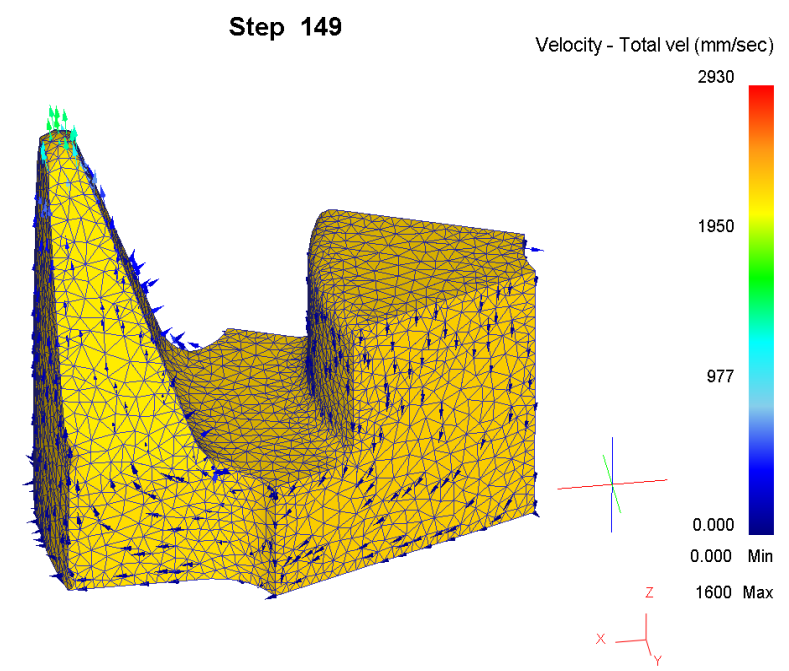

(f)

Figure 5. Billet deformation analysis of second step forging: (a) 90step; (b) 115step; (c) 135step; (d) 140step; (e) 145step; (f) 149step. 


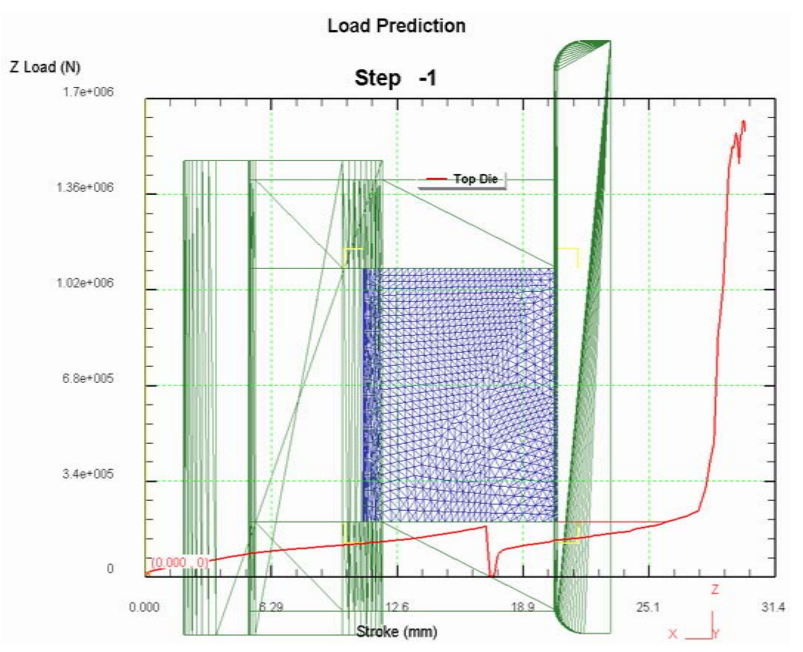

(a)

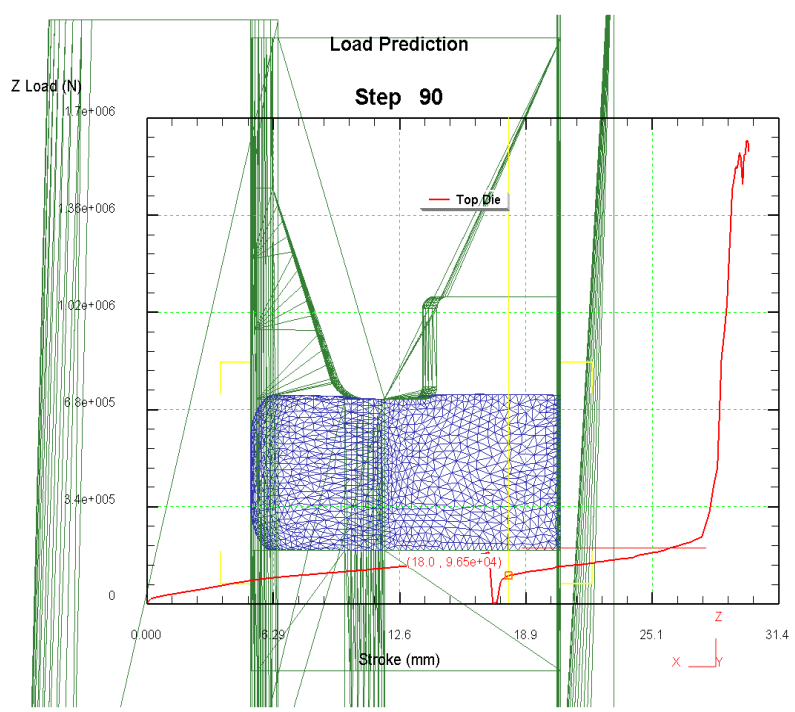

(c)

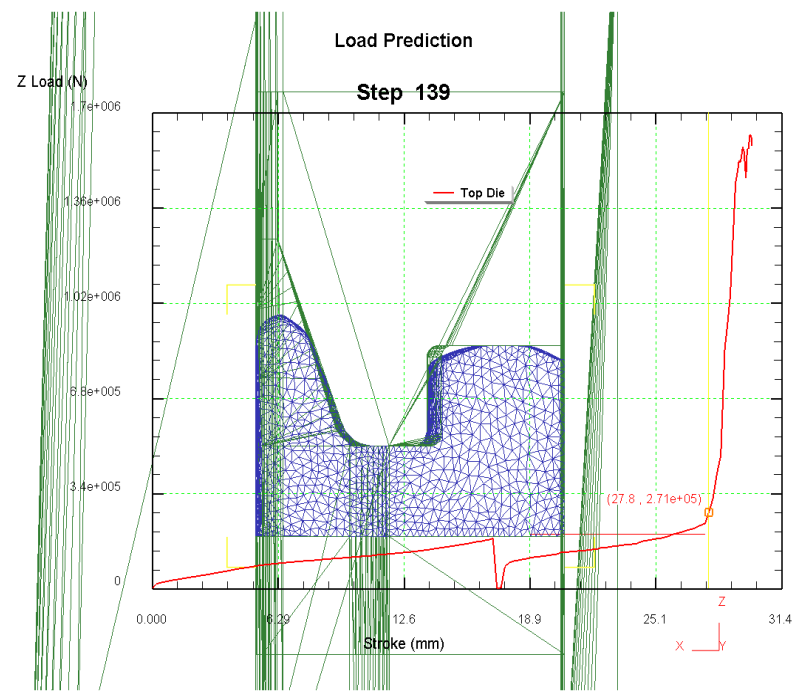

(e)

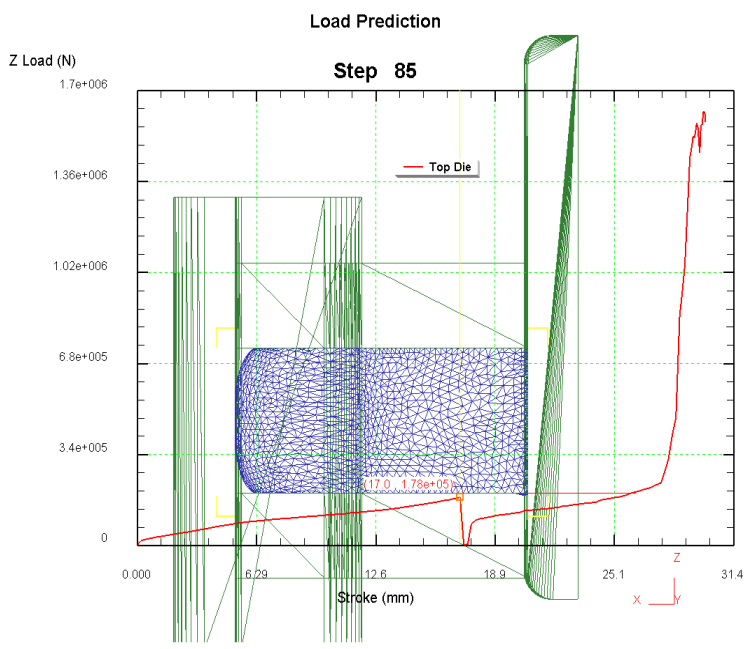

(b)

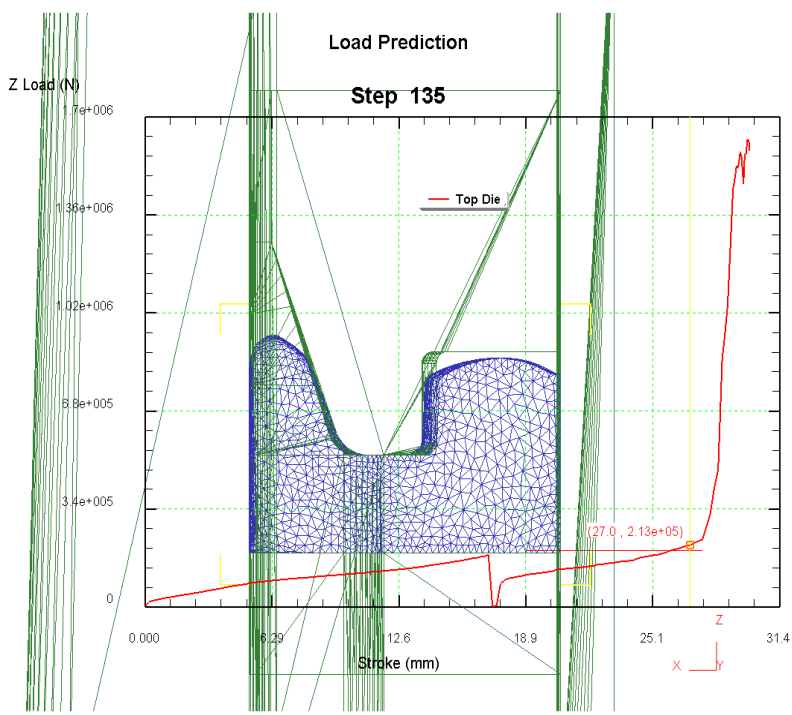

(d)
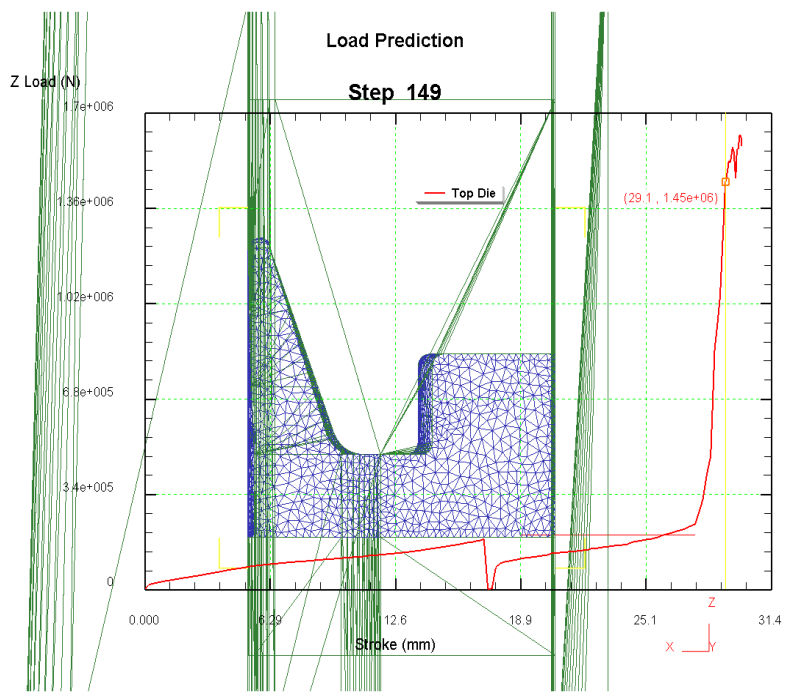

(f)

Figure 6. Stroke-load curve (a) 1step; (b) 85step; (c) 90step; (d) 135step; (e) 139step; (f)149step. 
flow mode changed, the forging load increased sharply. Changing the flow mode and keeping a free flow at the final forging will be benefit to forging load and die life.

\section{Improved Process}

Based on the analysis of the forging load, an improved process is put forward. Firstly, an improved pre-forging, as shown in Figure 7(a), which gathered more metal at the tooth part, was formed by radial forging. Secondly, the middle boss and pole claws, as shown in Figure 7(b), were formed by backward extrusion on the improved bottom base, which kept the middle boss cavity and pole claws cavity to full of at the same time.

Figure 8 shows the metal flow results of the improved process. At the first step forging, more metal will be gathered at the tooth part by changing the shape of the punch and the counterpunch, as shown in Figure 8(a).

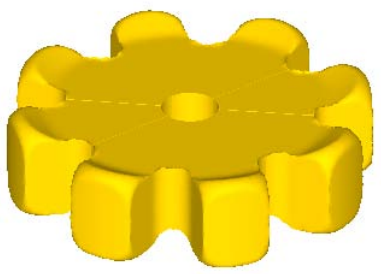

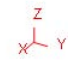

(a)
Then this pre-forging was forged by the second step toolset, as the effect of the special shape of pre-forging, the filling height of the pole claw cavity will be higher than that of the middle boss cavity at the early stage in the second step forging, as shown in Figure 8(b). This filling tendency will be kept until the final forging, the pole claw cavity and the middle boss cavity will be filled at the same time, as shown in Figure 8(c).

Figure 9 shows the forging load comparison of both processes. Two curves have the similar shape. At the first step forging, load increased slowly, then load had a decrease as the tool was exchanged, both load increased slowly at the early stage of the second step forging and both load increased sharply at final forging stage, but the final forging load of improved process was $740 \mathrm{kN}$, an decrease of $49 \%$ when compared with the former two steps forging process.

Step 197
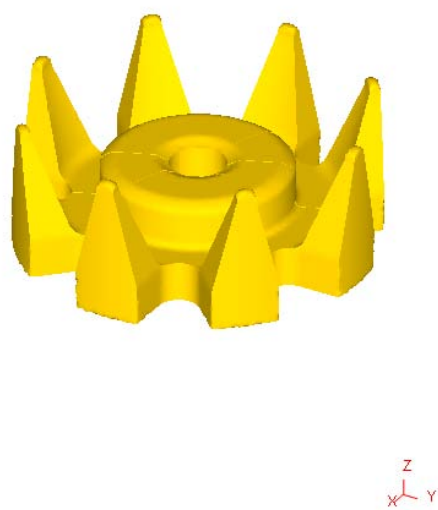

(b)

Figure 7. Improved forming process (a) Pre-forging; (b) Final forging.

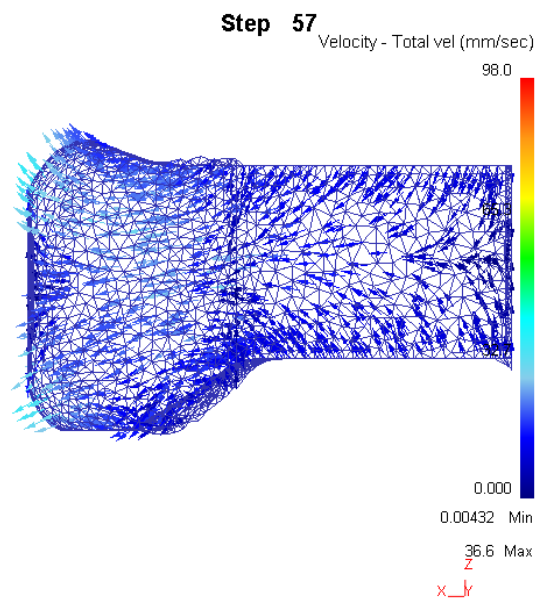

(a)

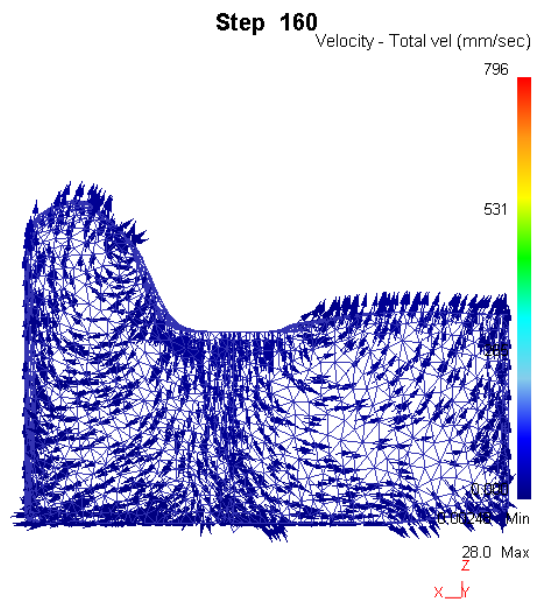

(b)

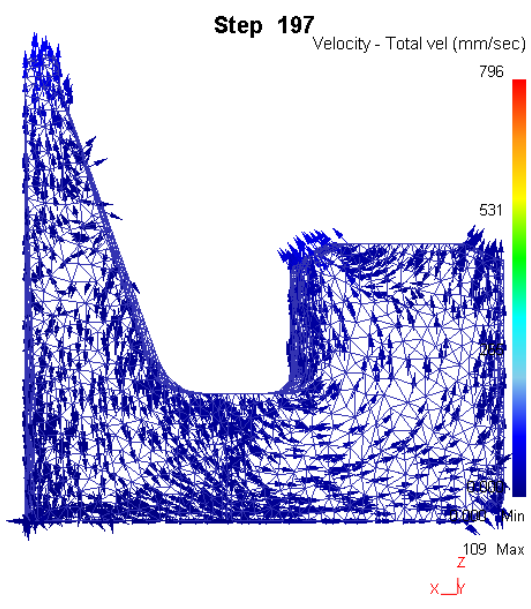

(c)

Figure 8. Material flow results of the improved process: (a) 57step; (b) 160step; (c) 197step. 


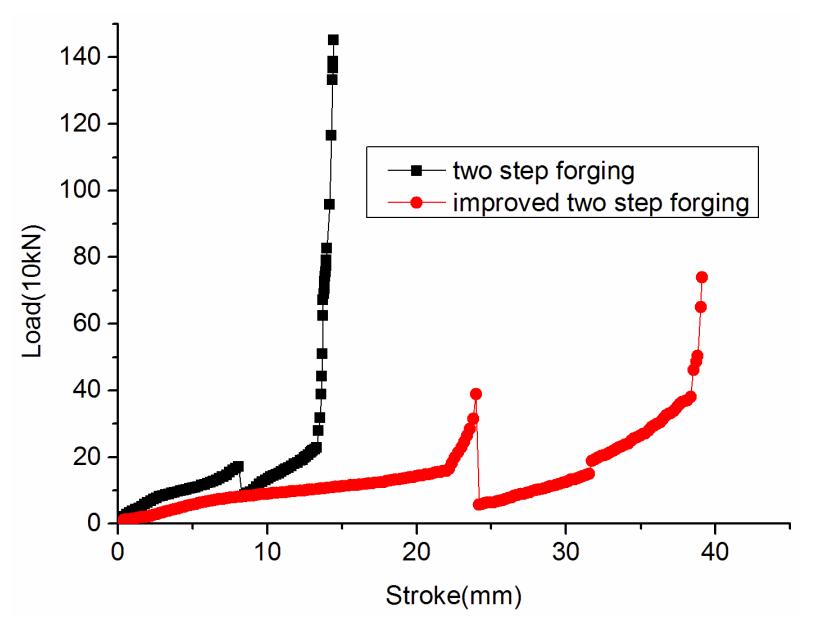

Figure 9. Forging load comparison of both processes.

\section{Conclusions}

The finite element analysis was performed to investigate the material flow and forging load. As a result of this study, the following conclusions can be drawn:

Based on the analysis of the billet deformation and material flow, a filling well forging without overlap defects can be obtained by both processes.

In the conventional two steps forging process, the middle boss cavity will be fully filled firstly. As the free flow was drastically reduced and it is this sharp reduced that required high forming load. The finish forging load reaches $1450 \mathrm{kN}$. Because more metal was gathered at the tooth part in the improved process, the pole claw cavity and the middle boss cavity will be filled at the same time, which can considerably reduce the final forging load.

\section{Acknowledgements}

This work is supported by the National Natural Science Foundation of China (Grant No. 50975222), Natural Science Foundation of Education Department of Shaanxi Provincial Government (Grant No. 11JK0801).

\section{REFERENCES}

[1] M. Kato and Ibaragi, "Method of Manufacture of a Magnetic Rotor Core Member for a Dynamoelectric Machine," United States Patent, 4759117, 1988-7-26.

[2] H. H. Koch and E. F. Sargeaunt, "Method and Machine for Rroviding Alternator Pole Pieces," United States Patent, 4635351, 1987-1-13.

[3] T. Awano and Y. Oishi, "Process for Making a Flanged Metal Product Having Raised Portions around Its Flange,” United States Patent, 3769696, 1973-11-6.

[4] S. Z. Hong and Z. P. Zeng, Hot Working Technology, 4, 2000, p. 32.

[5] M. Zhang and X. X. Cui, Metal Forming Machinery, 3, 2002, p. 122.

[6] Y. C. Gao, L. Hua and Y. M. Zhao, China Mechnical Engineering, 6, 2005, p. 1110.

[7] Y. H. Peng, "Simulation Technology of Metal Plastic Forming," Shanghai Jiao Tong University Press, 1999, p. 36.

[8] E. Korner and R. Knodler, "Possibilities in Warm Extrusion in Combination with Cold Extrusion," Journal of Materials Processing Technology, Vol. 35, 1992, pp. 451465. http://dx.doi.org/10.1016/0924-0136(92)90334-O

[9] E. Doege and R. Bohnsack, Journal of Materials Processing Technology, Vol. 98, 2000, pp. 165-170. http://dx.doi.org/10.1016/S0924-0136(99)00194-6 